\title{
Glycosylated coumarins, flavonoids, lignans and phenylpropanoids from Wikstroemia nutans and their biological activities
}

\author{
Meifang $\mathrm{Wu}^{\ddagger}$, Xiangdong Su $\mathrm{Su}^{\ddagger}$, Yichuang Wu, Yuanjing Luo, Ying Guo and Yongbo Xue*
}

Open Access

\author{
Full Research Paper \\ Address: \\ School of Pharmaceutical Sciences (Shenzhen), Sun Yat-sen \\ University, No. 66 Gongchang Road, Shenzhen, 518107, China \\ Email: \\ Yongbo Xue* - xueyb@mail.sysu.edu.cn \\ * Corresponding author $\ddagger$ Equal contributors \\ Keywords: \\ coumarin glucosides; flavonoids; lignans; structure elucidation; \\ Wikstroemia nutans
}

Beilstein J. Org. Chem. 2022, 18, 200-207. https://doi.org/10.3762/bjoc.18.23

Received: 10 December 2021

Accepted: 31 January 2022

Published: 16 February 2022

Associate Editor: S. Bräse

(C) 2022 Wu et al.; licensee Beilstein-Institut.

License and terms: see end of document.

\begin{abstract}
Wikstroemia nutans Champ. ex Benth., a traditional herbal medicine collected at the Lingnan region of China, was chemically investigated. A new biscoumarin glucoside, wikstronutin (1), along with three known bis- and tricoumarin glucosides (2-4), two flavonoid glycosides (5-6), and eleven lignan glucosides (7-17) were isolated from the stems and roots of W. nutans. The new structure including its absolute configuration was elucidated based on a combination of 1D and 2D NMR, UV, IR, HRESIMS spectroscopic data, as well as chemical transformation. Compounds 1-17 were first isolated from the plant species W. nutans, while compounds 1-3, 8, and 11 were reported from the genus Wikstroemia for the first time. All co-isolates were evaluated for their in vitro inhibitory effects on nitric oxide (NO) production induced by lipopolysaccharide (LPS) in murine RAW264.7 macrophage cells. The antibacterial activity of the selected compounds was also tested. Our work enriches the structure diversity of the secondary metabolites from the genus Wikstroemia.
\end{abstract}

\section{Introduction}

The genus Wikstroemia (Thymelaeaceae) contains approximately 62 species, which are widespread throughout the subtropical regions of Asia and Oceania [1]. Nineteen species of the genus Wikstroemia are found to be domestic in China, such as W. nutans, W. indica, and W. canescens [2]. Previous investigations have not only reported diverse secondary metabolites from the genus, but also promising pharmacological activities of the extracts and chemical constituents produced by Wikstroemia species, including cardiovascular, neuroprotective, hepatoprotective, anti-inflammatory, and antitumor activities $[1,3]$. The plant species $W$. nutans is widely distributed in the areas of the Guangdong and Guangxi provinces of China, and the whole plants of this species are used as a folk medicine for the treatment of arthritis, mastitis, and pain relief [2]. Interestingly, the traditional medical usages are highly consistent with the phytologically related medicinal plant species $W$. indica that has already been approved to use as a prescription drug in China [3]. Owing to the intriguing therapeutic effects associat- 
ed with $W$. indica, extensive phytochemical studies on $W$. indica have been pursed [3,4]. However, there is no report on the phytochemical and pharmacological investigations upon W. nutans.

Coumarins (2H-1-benzopyran-2-one) are a large quantity of phenolic substances found in plants and microorganisms [5]. These naturally occurring coumarins were well documented due to their diverse chemical structures and promising biological properties, such as anticancer, antitubercular, anti-inflammatory, anticoagulant, antibacterial, and neuroprotective effects [6]. As part of a continuing study of our group targeting at the identification of bioactive natural products from the medicinal plants and endophytes $[7,8]$, the chemical constituents of the stems and roots of $W$. nutans were investigated. This work resulted into the isolation and identification of a new biscoumarin glucoside $\mathbf{1}$, together with three known bis- and tricoumarin glucosides 2-4, two flavonoid glycosides 5 and $\mathbf{6}$,

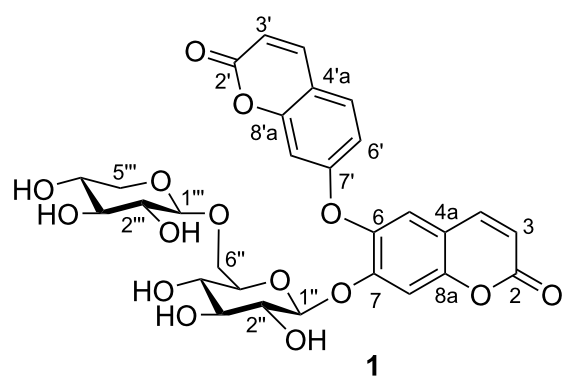<smiles>COc1ccc2cc(Oc3ccc4ccc(=O)oc4c3)c(=O)oc2c1-c1c(O)ccc2ccc(=O)oc12</smiles><smiles>O=c1ccc2ccc(Oc3cc4ccc(=O)oc4cc3OC(O)(Cl)Cl)cc2o1</smiles><smiles>COc1cc2cc(Oc3ccc4ccc(=O)oc4c3)c(=O)oc2cc1OOC(O)C(O)C(O)CC(C)(O)CC(=O)O</smiles><smiles>C=CCCC</smiles><smiles>[R]c1cc([C@H]2OC[C@H]3[C@H]4CO[C@H](c5cc([R])c([R])c([R])c5)[C@@]34CO2)cc([R])c1[R]</smiles>

$\begin{array}{llllllc} & \mathrm{R}^{1} & \mathrm{R}^{2} & \mathrm{R}^{3} & \mathrm{R}^{4} & \mathrm{R}^{5} & \mathrm{R}^{6} \\ 10 & \mathrm{H} & \mathrm{OH} & \mathrm{OMe} & \mathrm{OMe} & \mathrm{OH} & \mathrm{H} \\ 11 & \mathrm{H} & \mathrm{OMe} & \mathrm{OH} & \mathrm{OGlc} & \mathrm{OMe} & \mathrm{H} \\ 12 & \mathrm{OMe} & \mathrm{OH} & \mathrm{H} & \mathrm{OMe} & \mathrm{OGlc} & \mathrm{OMe} \\ 13 & \mathrm{OMe} & \mathrm{OH} & \mathrm{OMe} & \text { OMe } & \text { OGlc } & \text { OMe } \\ 14 & \mathrm{H} & \mathrm{OGlc} & \mathrm{OMe} & \mathrm{OMe} & \text { OGlc } & \mathrm{H} \\ 15 & \text { OMe } & \text { OGlc } & \text { OMe } & \text { OMe } & \text { OGlc } & \text { OMe }\end{array}$<smiles>[R1]C/C=C/c1cc(OC)c2c(c1)[C@@H](CO)[C@@H](c1cc([R])c(OC)c(OC)c1)O2</smiles><smiles>COc1cc(/C=C/CO)cc(OC)c1OC</smiles>

16<smiles>COc1cc([C@@H](O)[C@H](CO)Oc2ccc(/C=C/CO)cc2OC)ccc1OC1CCCCC1</smiles>

17 
and eleven lignan glucosides 7-17 (Figure 1). Herein, we present the isolation and structural elucidation of these natural products and their in vitro biological activities.

\section{Results and Discussion}

Compound 1 was obtained as a yellowish, amorphous powder. Its molecular formula was determined as $\mathrm{C}_{29} \mathrm{H}_{28} \mathrm{O}_{15}$ based on the HRESIMS sodium adduct ion observed at $\mathrm{m} / \mathrm{z} 639.1319$ $\left([\mathrm{M}+\mathrm{Na}]^{+}\right.$, calcd for $\left.\mathrm{C}_{29} \mathrm{H}_{28} \mathrm{O}_{15} \mathrm{Na}^{+}, 639.1320\right)$, indicating sixteen degrees of unsaturation. Its UV absorption bands at 325 and $293 \mathrm{~nm}$ indicated the presence of a coumarin-type chromophore. The IR spectrum of $\mathbf{1}$ demonstrated absorption bands characteristic for an hydroxy group $\left(3266 \mathrm{~cm}^{-1}\right), \alpha, \beta$-unsaturated carbonyl group (1739 and $\left.1701 \mathrm{~cm}^{-1}\right)$, and an aromatic ring (1624 and $1457 \mathrm{~cm}^{-1}$ ). The ${ }^{1} \mathrm{H}$ NMR spectrum of $\mathbf{1}$
(Table 1) exhibited downfield chemical shifts corresponding to two pairs of olefinic protons with the $\mathrm{AB}$ coupling patterns at $\delta_{\mathrm{H}} 7.70(\mathrm{~d}, J=9.5 \mathrm{~Hz}, \mathrm{H}-4), 7.67$ (d, $J=9.5 \mathrm{~Hz}, \mathrm{H}-4$ '), 6.40 (d, $J=9.5 \mathrm{~Hz}, \mathrm{H}-3)$, and $6.34\left(\mathrm{~d}, J=9.5 \mathrm{~Hz}, \mathrm{H}-3^{\prime}\right)$, a typical ABX coupling system at $\delta_{\mathrm{H}} 7.46\left(\mathrm{~d}, J=8.5 \mathrm{~Hz}, \mathrm{H}-5^{\prime}\right), 7.01(\mathrm{dd}, J=$ 8.5, 2.4 Hz, H-6'), 7.02 (d, $J=2.4 \mathrm{~Hz}, \mathrm{H}-8^{\prime}$ ), suggesting the presence of a 1,2,3-trisubstituted benzene ring, and two metacoupling protons at $\delta_{\mathrm{H}} 7.81(\mathrm{~s}, \mathrm{H}-8)$ and $7.40(\mathrm{~s}, \mathrm{H}-5)$, indicating a 1,3,4,6-tetrasubstituted benzene ring. Additionally, the ${ }^{1} \mathrm{H}$ NMR spectrum revealed distinctive peaks for two anomeric protons at $\delta_{\mathrm{H}} 5.71\left(\mathrm{~d}, J=7.7 \mathrm{~Hz}, \mathrm{H}-1^{\prime \prime}\right)$ and $4.94(\mathrm{~d}, J=7.1 \mathrm{~Hz}$, $\mathrm{H}-1^{\prime \prime \prime)}$, implied the co-existences of two sugar moieties. Analyses of the ${ }^{13} \mathrm{C}$ NMR (Table 1) coupled with DEPT and HSQC spectra of $\mathbf{1}$ displayed 29 carbon signals assignable to two ester carbonyls $\left(\delta_{C} 161.3\right.$ and 161.1$)$, seven $s^{2}$ quaternary

Table 1: ${ }^{1} \mathrm{H}$ and ${ }^{13} \mathrm{C}$ NMR Spectroscopic Data for $\mathbf{1}(\delta$ in ppm, $J$ in $\mathrm{Hz})$.

\begin{tabular}{|c|c|c|c|c|}
\hline position & $\delta_{C}^{a}$ & $\delta_{H^{a}}$ & $\delta_{c}^{b}$ & $\delta_{H^{b}}$ \\
\hline 2 & 161.3 & & 160.1 & \\
\hline 3 & 115.4 & $6.40(1 \mathrm{H}, \mathrm{d}, 9.5)$ & $114.11^{c}$ & $6.40(1 \mathrm{H}, \mathrm{d}, 9.5)$ \\
\hline 4 & 143.7 & $7.70(1 \mathrm{H}, \mathrm{d}, 9.5)$ & 143.7 & $7.96(1 \mathrm{H}, \mathrm{d}, 9.5)$ \\
\hline $4 a$ & 114.3 & & 113.3 & \\
\hline 5 & 121.4 & $7.40(1 \mathrm{H}, \mathrm{s})$ & 120.7 & $7.58(1 \mathrm{H}, \mathrm{s})$ \\
\hline 6 & 153.5 & & $152.04^{c}$ & \\
\hline 7 & 154.0 & & $152.06^{c}$ & \\
\hline 8 & 106.5 & $7.81(1 \mathrm{H}, \mathrm{s})$ & 104.5 & $7.41(\mathrm{~s}, 1 \mathrm{H})$ \\
\hline $8 a$ & 141.5 & & 140.4 & \\
\hline $2^{\prime}$ & 161.1 & & 160.0 & \\
\hline $3^{\prime}$ & 115.0 & $6.34(1 \mathrm{H}, \mathrm{d}, 9.5)$ & 113.7 & $6.36(1 \mathrm{H}, \mathrm{d}, 9.5)$ \\
\hline $4^{\prime}$ & 144.2 & $7.67(1 \mathrm{H}, \mathrm{d}, 9.5)$ & 141.2 & $8.03(1 \mathrm{H}, \mathrm{d}, 9.5)$ \\
\hline 4'a & 114.7 & & $114.13^{c}$ & \\
\hline $5^{\prime}$ & 130.3 & $7.46(1 \mathrm{H}, \mathrm{d}, 8.5)$ & 129.9 & $7.68(1 \mathrm{H}, \mathrm{d}, 8.4)$ \\
\hline $6^{\prime}$ & 114.2 & $7.01(1 \mathrm{H}, \mathrm{dd}, 8.5,2.4)$ & 113.6 & $6.94-6.96(1 \mathrm{H}, \mathrm{m})$ \\
\hline $7^{\prime}$ & 162.2 & & 160.6 & \\
\hline $8^{\prime}$ & 105.3 & $7.02(1 \mathrm{H}, \mathrm{d}, 2.4)$ & 104.2 & $6.94-6.96(1 \mathrm{H}, \mathrm{m})$ \\
\hline 8'a & 156.4 & & 155.0 & \\
\hline Glc-C-1" & 103.0 & $5.71(1 \mathrm{H}, \mathrm{d}, 7.7)$ & 100.1 & $5.11(1 \mathrm{H}, \mathrm{d}, 7.8)$ \\
\hline Glc-C-2" & $74.8^{c}$ & 4.10-4.15 $(1 \mathrm{H}, \mathrm{m})$ & 72.9 & 3.04-3.09 (1H, m) \\
\hline Glc-C-3" & $77.9^{c}$ & $4.35-4.42(1 \mathrm{H}, \mathrm{m})$ & 76.5 & $3.25(1 \mathrm{H}, \mathrm{t}, 9.0)$ \\
\hline Glc-C-4" & 71.4 & $4.35-4.42(1 \mathrm{H}, \mathrm{m})$ & 69.2 & $3.15-3.18(1 \mathrm{H}, \mathrm{m})$ \\
\hline Glc-C-5" & 79.0 & $4.10-4.15(1 \mathrm{H}, \mathrm{m})$ & 75.5 & 3.59-3.63 (1H, m) \\
\hline Glc-C-6" & 70.6 & $\begin{array}{l}4.35-4.42(1 \mathrm{H}, \mathrm{m}) \\
4.75-4.77(1 \mathrm{H}, \mathrm{m})\end{array}$ & 68.3 & $\begin{array}{l}3.90(1 \mathrm{H}, \mathrm{d}, 9.7) \\
3.59-3.63(1 \mathrm{H}, \mathrm{m})\end{array}$ \\
\hline Xyl-C-1"' & 106.8 & $4.94(1 \mathrm{H}, \mathrm{d}, 7.1)$ & 104.1 & $4.13(1 \mathrm{H}, \mathrm{d}, 7.5)$ \\
\hline Xyl-C-2"' & $75.4^{c}$ & $4.10-4.15(1 \mathrm{H}, \mathrm{m})$ & 73.3 & 2.95-2.97 (1H, m) \\
\hline Xyl-C-3"' & 78.9 & $4.30(1 \mathrm{H}, \mathrm{t}, 9.0)$ & 76.6 & 3.04-3.09 (1H, m) \\
\hline Xyl-C-4"' & 71.5 & $4.20(1 \mathrm{H}, \mathrm{t}, 9.0)$ & 69.4 & 3.29-3.31 (1H, m) \\
\hline Xyl-C-5"' & 67.7 & $\begin{array}{l}3.65-3.68(1 \mathrm{H}, \mathrm{m}) \\
4.35-4.42(1 \mathrm{H}, \mathrm{m})\end{array}$ & 65.7 & $\begin{array}{l}3.69(1 \mathrm{H}, \mathrm{dd}, 5.3,11.2) \\
2.95-2.97(1 \mathrm{H}, \mathrm{m})\end{array}$ \\
\hline
\end{tabular}

aspectra were recorded in pyridine- $d_{5}\left(600 \mathrm{MHz}\right.$ for ${ }^{1} \mathrm{H}$ and $150 \mathrm{MHz}$ for $\left.{ }^{13} \mathrm{C}\right) ;{ }^{b}$ spectra were recorded in $\mathrm{DMSO}-d_{6}\left(800 \mathrm{MHz}\right.$ for ${ }^{1} \mathrm{H}$ and $200 \mathrm{MHz}$ for ${ }^{13} \mathrm{C}$ ); assignments were confirmed by ${ }^{1} \mathrm{H}-{ }^{1} \mathrm{H}$ COSY, HSQC, HMBC and ROESY experiments; ${ }^{\circ}$ overlapped. 
carbons (including five $O$-bearing aromatic carbons at $\delta_{\mathrm{C}} 162.2$, 156.4, 154.0, 153.5, and 141.5; and two aromatic carbons at $\delta_{\mathrm{C}}$ 114.7 and 114.3), nine methine groups $\left(\delta_{\mathrm{C}} 115.4,143.7,121.4\right.$, $106.5,115.0,144.2,130.3,114.2,105.3)$, nine oxygenated methine carbon atoms $\left(\delta_{\mathrm{C}} 106.8,103.0,79.0,78.9,77.9,75.4\right.$, $74.8,71.4,71.5)$, as well as two oxygenated methylenes resonated at $\delta_{\mathrm{C}} 70.6$, and 67.7 , respectively. The aforementioned information suggested that compound $\mathbf{1}$ is likely a biscoumarin glycoside [9].

The substructures A and B (Figure 2 and Figure 3) were elucidated based on the HMBC correlations from $\mathrm{H}-4\left(\delta_{\mathrm{H}} 7.70\right)$ to C-2 $\left(\delta_{C} 161.3\right), C-5\left(\delta_{C} 121.4\right)$, and C-6 $\left(\delta_{C} 153.5\right)$, together with a ${ }^{1} \mathrm{H}-{ }^{1} \mathrm{H}$ COSY correlation between $\mathrm{H}-3$ and $\mathrm{H}-4$ (substructure A), while the HMBC cross-peaks from $\mathrm{H}-4{ }^{\prime}\left(\delta_{\mathrm{H}}\right.$ 7.67) to $\mathrm{C}-2^{\prime}\left(\delta_{\mathrm{C}} 161.1\right), \mathrm{C}-5{ }^{\prime}\left(\delta_{\mathrm{C}} 130.3\right)$, and $\mathrm{C}-8 \mathrm{a}\left(\delta_{\mathrm{C}} 141.5\right)$, along with the two spin-spin systems of $\mathrm{H}-3^{\prime} / \mathrm{H}-4^{\prime}$ and $\mathrm{H}-5^{\prime} / \mathrm{H}-6^{\prime}$ (substructure B) depicted in the ${ }^{1} \mathrm{H}_{-}{ }^{1} \mathrm{H}$ COSY of 1. Although the direct evidence between substructures $\mathrm{A}$ and $\mathrm{B}$ was missing, to our delighted, the key ROESY correlation of $\mathrm{H}-5 / \mathrm{H}-8^{\prime}$ (Figure 3 and Supporting Information File 1, Figure S34, re-

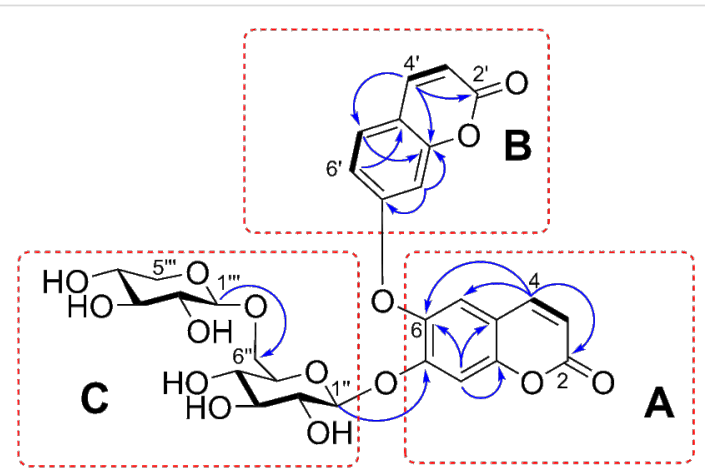

Figure 2: The key correlations observed in the ${ }^{1} \mathrm{H}-{ }^{1} \mathrm{H}$ COSY (bold bonds), HMBC (blue) correlations of $\mathbf{1}$ (recorded in pyridine- $d_{5}$, $600 \mathrm{MHz}$ ). corded in DMSO- $\left.d_{6}\right)$ established the $\mathrm{C}(6)-\mathrm{O}-\mathrm{C}\left(7^{\prime}\right)$ ether linkage. Therefore, a bis-coumarin-based aglycone was determined as shown (Figure 1), which is identical with that of daphnogitin [10].

In addition, two sugar units in substructure $C$ (Figure 2 and Figure 3), including a $\beta$-glucopyranosyl and a $\beta$-xylopyranosyl were confirmed by the interpretation of key signals observed in the ${ }^{1} \mathrm{H}_{-}{ }^{1} \mathrm{H}$ COSY, HSQC, HMBC, and NOSEY spectra of $\mathbf{1}$. The $\beta$-configurations of the glucopyranosyl and xylopyranosyl units were determined by the relatively large coupling constants $(J=7.8$ and $7.1 \mathrm{~Hz})$ of their anomeric protons, respectively. The ROESY spectrum (Supporting Information File 1, Figure S34, recorded in DMSO- $d_{6}$ ) showed correlations of H-3" and $\mathrm{H}-1 " / \mathrm{H}-5$ "/HO-4", indicating the D-configuration of glucose, while the ROESY correlations of H-1"'/H-3"'/H-5"', H-3"'/H-5'", and H-2'"/H-4"' implied the xylose should be in D-configuration (Figure 3). The key HMBC correlations of $\delta_{H}$ 4.35 and 4.75 (Glc H-6") with $\delta_{\mathrm{C}} 106.8$ (Xyl C-1"') and the reverse correlation of $\delta_{\mathrm{H}} 4.94$ (Xyl H-1"') with $\delta_{\mathrm{C}} 170.6$ (Glc C-6") suggested the linkage of the xylopyranosyl moiety at C-6 of the glucopyranosyl unit. This deduction was further confirmed by a ROESY correlation between H-6" and H-1"'. Subsequently, an acid hydrolysis of $\mathbf{1}$ afforded the products including daphnogitin, a D-glucose, and a D-xylose. The absolute configurations of glucopyranosyl and xylopyranosyl was further determined by HPLC analysis of the sugar derivatives (Supporting Information File 1, Figure S4). The linkage between the substructures $\mathrm{A}$ and $\mathrm{C}$ was revealed by the crucial $\mathrm{HMBC}$ correlation between the anomeric proton at Glc H-1" $\left(\delta_{\mathrm{H}} 5.71\right) /$ C-7 $\left(\delta_{C} 154.0\right)$. Therefore, the gross structure of 1 was determined as shown and the trivial name wikstronutin was given.

Sixteen known compounds were isolated and their structures were determined as 7-( $\beta$-D-glucopyranosyloxy)-7'-hydroxy-3[(2-oxo-2H-1-benzopyran-7-yl)oxy]-[8,8'-bis(2H-1-benzo-
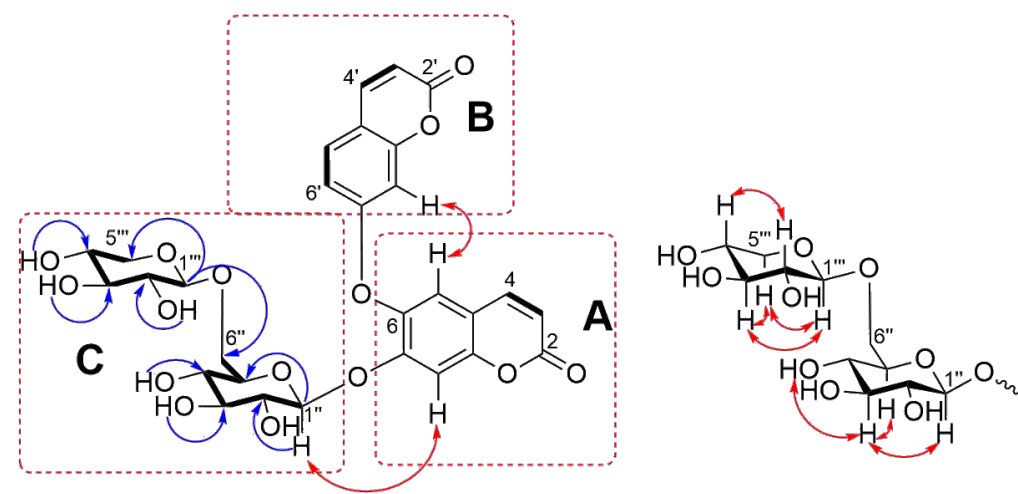

Figure 3: The key correlations observed in the ${ }^{1} \mathrm{H}-{ }^{1} \mathrm{H}$ COSY (bold bonds), HMBC (blue), ROESY (red) of 1 (recorded in DMSO- $d_{6}, 800 \mathrm{MHz}$ ). 
pyran)]-2,2'-dione (2) [11], 6-( $\beta$-D-glucopyranosyloxy)-7-[(2oxo-2H-1-benzopyran-7-yl)oxy]-2H-1-benzopyran-2-one (3) [9], rutarensin (4) [12], hirsutrin (5) [13], genkwanin 5-O- $\beta$-Dprimeveroside (6) [14], (7S,8R)-5-methoxydehydrodiconiferyl alcohol 4-O- $\beta$-D-glucopyranoside (7) [15], 9'-methoxydehydrodiconiferyl alcohol 4-O- $\beta$-D-glucopyranoside (8) [16], dehydrodiconiferyl alcohol-4-O- $\beta$-D-glucopyranoside (9) [17] (+)-pinoresinol (10) [18], 4,4'-dimethoxy-3'-hydroxy-7,9':7',9diepoxylignan-3-O- $\beta$-D-glucopyranoside (11) [19], (+)-medioresinol 4-O- $\beta$-D-glucopyranoside (12) [20], $(+)$-springaresinol-4"-O- $\beta$-D-monoglucopyranoside (13) [21], $(+)$-pinoresinol di-O- $\beta$-D-glucopyranoside (14) [22], liriodendrin (15) [23], syringin (16) [24], and citrusin A (17) [25] (Figure 1) by comparison to literature data. In addition, compounds $2, \mathbf{3}, \mathbf{8}$, and $\mathbf{1 1}$ were isolated for the first time from the genus Wikstroemia.

\section{Biological activity}

Considered naturally occurring glycosides of phenolic metabolites usually exhibit anti-inflammatory activity in literature [26], compounds 1-17 were evaluated for their inhibitory activities against LPS-induced nitric oxide (NO) production in RAW 264.7 mouse macrophages. All of them showed mild inhibitory activities with inhibition rates of $10-20 \%$ at a concentration of $50 \mu \mathrm{M}$ (Table 2). Since coumarin derivatives were reported to have antimicrobial activities [27], the antimicrobial activity of compounds 1-4 was also evaluated against the bacteria Escherichia coli, Staphylococcus aureus subsp. aureus, Salmonella enterica subsp. enterica, and Pseudomonas aeruginosa. However, all of them were found to be devoid of inhibitory activity (MIC $>250 \mu \mathrm{g} / \mathrm{mL}$ ).

\begin{tabular}{llll}
$\begin{array}{l}\text { Table 2: Inhibitory activities of compounds } \mathbf{1 - 1 7} \text { on LPS-stimulated } \\
\text { NO production. }\end{array}$ & & \\
compound & inhibition (\%) & compound & inhibition (\%) \\
\hline $\mathbf{1}$ & $16.15 \pm 1.10$ & $\mathbf{1 0}$ & $13.85 \pm 1.54$ \\
$\mathbf{2}$ & $10.73 \pm 1.17$ & $\mathbf{1 1}$ & $18.26 \pm 0.59$ \\
$\mathbf{3}$ & $15.21 \pm 1.51$ & $\mathbf{1 2}$ & $15.90 \pm 1.24$ \\
$\mathbf{4}$ & $16.88 \pm 1.33$ & $\mathbf{1 3}$ & $19.58 \pm 0.83$ \\
$\mathbf{5}$ & $15.43 \pm 1.22$ & $\mathbf{1 4}$ & $15.42 \pm 0.38$ \\
$\mathbf{6}$ & $13.68 \pm 1.77$ & $\mathbf{1 5}$ & $15.73 \pm 1.41$ \\
$\mathbf{7}$ & $20.42 \pm 1.06$ & $\mathbf{1 6}$ & $\mathbf{8 . 1 6} \pm 1.52$ \\
$\mathbf{8}$ & $18.45 \pm 1.65$ & $\mathbf{1 7}$ & $7.85 \pm 0.74$ \\
$\mathbf{9}$ & $19.51 \pm 1.11$ & L-NMMA $^{\mathrm{b}}$ & $52.45 \pm 1.13$ \\
\hline
\end{tabular}

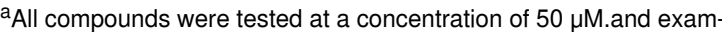

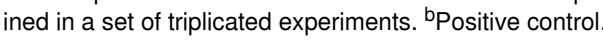

\section{Conclusion}

In this paper, the new bis-coumarin glucoside wikstronutin (1) was isolated from the stems and roots of the medicinal plant species W. nutans, together with three known bis- and tricoumarin glucosides 2-4, two flavonoid glycosides $\mathbf{5}$ and $\mathbf{6}$, and eleven lignan glucosides 7-17. Their structures were established by extensive spectroscopic analyses, including 1D, 2D NMR spectroscopy, and HRESIMS. The relative and absolute structure of $\mathbf{1}$ was unambiguously determined based on ROESY experiments and chemical transformation. In the vitro bioassays, compounds 1-17 showed a mild inhibitory effect against nitric oxide (NO) production in LPS-stimulated RAW 264.7 mouse macrophages. The antibacterial activities of compounds 1-4 against Escherichia coli, Staphylococcus aureus subsp. aureus, Salmonella enterica subsp. enterica, and Pseudomonas aeruginosa were also tested, however, none of them showed antimicrobial activities. This is the first report of the isolation of coumarins, flavonoids, lignans and phenylpropanoid glycosides from $W$. nutans, while compounds $\mathbf{1}-\mathbf{3}, \mathbf{8}$, and $\mathbf{1 1}$ was encountered from the genus Wikstroemia for the first time. Our work will enrich the chemistry and structure diversity of natural products generated by plant species from the genus Wikstroemia.

\section{Experimental \\ General experimental procedures}

Optical rotations were measured with a Horiba SEPA-300 polarimeter. UV spectra were recorded using a Waters UV-2401A spectrophotometer equipped with a DAD and a $1 \mathrm{~cm}$ path length cell. Methanolic samples were scanned from 190 to $400 \mathrm{~nm}$ in $1 \mathrm{~nm}$ steps. IR spectra were obtained using a Tensor 27 spectrophotometer with $\mathrm{KBr}$ pellets. 1D and 2D NMR spectra were acquired on Bruker DRX-600 and DRX800 spectrometers with TMS as internal standard. Chemical shifts $(\delta)$ were expressed in ppm with reference to the solvent signals. Mass spectra were recorded on a VG Auto Spec-3000 instrument or an API QSTAR Pulsar 1 spectrometer. Semipreparative HPLC was performed on an Agilent 1120 apparatus equipped with a UV detector and a Zorbax SB-C-18 (Agilent, $9.4 \mathrm{~mm} \times 25 \mathrm{~cm}$ ) column. Column chromatography was performed using silica gel (200-300 mesh and H, Qingdao Marine Chemical Co. Ltd., Qingdao, People's Republic of China), RP-18 gel (40-63 $\mu \mathrm{m}$, Merck, Darmstadt, Germany), and MCI gel (75-150 $\mu \mathrm{m}$; Mitsubishi Chemical Corporation, Japan). Fractions were monitored by TLC (GF254, Qingdao Marine Chemical Co. Ltd., Qingdao), and spots were visualized by heating silica gel plates sprayed with $10 \% \mathrm{H}_{2} \mathrm{SO}_{4}$ in EtOH. All solvents were distilled prior to use.

\section{Plant materials}

The dried stems and roots of $W$. nutans were collected in Xinzhou City of Guangxi Province, People's Republic of China, in August 2019, and authenticated by Prof. Yongbo Xue of the Research Department of Pharmacognosy, Sun Yat-sen Univer- 
sity. A voucher specimen (SYSUSZ-2019-X1) has been deposited in the Department of Natural Medicinal Chemistry, Sun Yat-sen University.

\section{Extraction and isolation}

The dried root of $W$. nutans $(3.5 \mathrm{~kg}$ ) was extracted using $95 \%$ aqueous ethanol $(15 \mathrm{~L} \times 4$ times $\times 2 \mathrm{~h}$ at room temperature) with ultrasonic assistance. The combined extracts were filtered and evaporated under reduced pressure to yield a green residue (350.6 g). The crude extract was suspended in distilled $\mathrm{H}_{2} \mathrm{O}$ ( $2 \mathrm{~L}$ ) and successively partitioned with $n$-BuOH and EtOAc. The EtOAc extract (EE) fraction (110 g) was chromatographed over a silica gel $(100-200 \mathrm{mesh})$ column $(20 \times 100 \mathrm{~cm})$, eluted with dichloromethane/methanol $(50: 1$ to $0: 1 \mathrm{v} / \mathrm{v})$ to afford 10 fractions (EE1-EE10). The fraction EE4 (13.3 g) was further purified by semi-preparative HPLC [phenyl column $(10 \times 250 \mathrm{~mm}, 5 \mu \mathrm{m}$ particle size $)$; mobile phase methanol/ water $(65: 35)$ to yield compound $\mathbf{1 0}(20.0 \mathrm{mg})$. The fraction EE8 (13.3 g) was subjected to a HP20 gel eluting with a solvent mixture of methanol $/ \mathrm{H}_{2} \mathrm{O}(20 \%$ to $100 \%$, v/v $)$ to produce six sub-fractions (EE8.1-8.6). The sub-fraction EE8.3 (250 mg) was further purified by semi-preparative HPLC; mobile phase methanol/water (75:35-50:60) to yield compounds 3 (20.0 mg) and $4(18.0 \mathrm{mg}), \mathbf{7}(7.0 \mathrm{mg})$, and $17(10.0 \mathrm{mg})$, respectively. The sub-fraction EE8.2 (310 mg) was also purified by semireparative HPLC; mobile phase methanol/water (65:35-30:70) to yield compounds $\mathbf{1 1}(25.0 \mathrm{mg}), \mathbf{1 2}(8.0 \mathrm{mg})$, and $\mathbf{1 3}(6.0 \mathrm{mg})$, respectively. The $n-\mathrm{BuOH}$ extract fraction $(40.7 \mathrm{~g})$ was chromatographed over a HP20 gel column $(10 \times 50 \mathrm{~cm})$, eluted with dichloromethane/methanol $(50: 1$ to $0: 1 \mathrm{v} / \mathrm{v})$ to afford 10 fractions (EE1-10). The $n$-BuOH extract $(40.75 \mathrm{mg}$ ) was initially fractionated by $\mathrm{HP} 20$ eluting with a $\mathrm{MeOH} / \mathrm{H}_{2} \mathrm{O}(20: 80-100: 0$ gradient system, $\mathrm{v} / \mathrm{v}$ ) to obtain five fractions (B1-B5). The fraction B3 (1.4 g), B4 (5.3 g), and B5 (3.8 g) were further separated by Sephadex LH-20 CC, respectively, eluting with $\mathrm{MeOH}$ yielded thirteen subfractions, B3.1-3.4, B4.1-4.5, and B5.1-5.4. The sub-fraction B3.2 was subjected to silica gel CC $\left(\mathrm{CH}_{2} \mathrm{Cl}_{2} / \mathrm{MeOH}, 5: 1-2: 1\right.$, v/v) yielded compounds 15 (30.0 mg) and $8(10.0 \mathrm{mg})$. The sub-fraction B4.2 (310 mg) was purified by semi-reparative; methanol/water ( $37: 63$ to $50: 50$ ); to yield compounds $\mathbf{9}(10.0 \mathrm{mg})$ and $\mathbf{1 4}(6 \mathrm{mg})$. The sub-fraction B5.4 $(310 \mathrm{mg}$ ) was chromatographed over a HW-40 CC eluting with $\mathrm{MeOH}$ to obtain six fractions (B5.4.1-5.4.6), further purified by semipreparative RP-HPLC using a mobile phase of $\mathrm{MeCN} / \mathrm{H}_{2} \mathrm{O}$ (20: 80-50: 50 gradient system, v/v, $3 \mathrm{~mL} / \mathrm{min}$ ) to afford compounds $\mathbf{1}$ (7.0 mg), 2 (15.0 mg), 5 (20.0 mg), and $\mathbf{6}(10.0 \mathrm{mg})$.

\section{Identification of new compounds}

Compound 1: Pale yellow powder; $[\alpha]_{\mathrm{D}}^{25}-38.05$ (c 0.1 , $\mathrm{MeOH}) ; \mathrm{UV}(\mathrm{MeOH}) \lambda_{\max } \mathrm{nm}(\log \varepsilon) 290$ (0.35), 324 (0.32); IR $v_{\text {max }}: 3266,2925,1739,1701,1624,1457,1261,1020,802$,
611, $405 \mathrm{~cm}^{-1} ;{ }^{1} \mathrm{H},{ }^{13} \mathrm{C}$ NMR data, see Table 1; ESIMS (positive ion mode): $(\mathrm{m} / \mathrm{z}) 617[\mathrm{M}+\mathrm{H}]^{+}$; HRESIMS (positive ion mode): $(\mathrm{m} / \mathrm{z})[\mathrm{M}+\mathrm{Na}]^{+}$, calcd for $\mathrm{C}_{29} \mathrm{H}_{28} \mathrm{O}_{15} \mathrm{Na}, 639.1320$; found, 639.1309 .

\section{Anti-inflammatory assay}

The RAW 264.7 cells $\left(2 \times 10^{5}\right.$ cells/well $)$ were incubated in 96-well culture plates with or without $1 \mu \mathrm{g} / \mathrm{mL}$ LPS (Sigma Chemical Co., USA) for $24 \mathrm{~h}$ in the presence or absence of the test compounds. Aliquots of supernatants $(50 \mu \mathrm{L})$ was then reacted with $100 \mu \mathrm{L}$ Griess reagent (Sigma Chemical Co., USA). The absorbance was measured at $570 \mathrm{~nm}$ using Synergy TMHT Microplate Reader (BioTek Instruments Inc., USA). In the study, L-NMMA (Sigma Chemical Co., USA) was used as a positive control. In the remaining medium, an MTT assay was carried out to determine whether the suppressive effect was related to cell viability. The inhibitory rate of NO production = (NO level of blank control - NO level of test samples)/NO level of blank control. The percentage of NO production was evaluated by measuring the amount of nitrite concentration in the supernatants with Griess reagent as described previously [28].

\section{Antimicrobial assay}

Compounds 1-4 were evaluated for their antimicrobial activities against Escherichia coli, Staphylococcus aureus subsp. aureus, Salmonella enterica subsp. enterica, and Pseudomonas aeruginosa. Antimicrobial assay was conducted by the previously described method [29]. Add the sample to be tested into the 96-well culture plate, the maximum concentration of the used compounds was $100 \mu \mathrm{M}$. Add bacteria liquid to each well, the final concentration is $5 \times 10^{5} \mathrm{CFU} / \mathrm{mL}$. Incubate at $37{ }^{\circ} \mathrm{C}$ for $24 \mathrm{~h}$, the OD value at $595 \mathrm{~nm}$ was measured by a microplate reader, and the medium blank control was set in the experiment.

\section{Determination of absolute configurations of sugar units of 1}

Compound 1 ( $2 \mathrm{mg}$ ) was hydrolyzed with $1 \mathrm{~N} \mathrm{HCl}(2 \mathrm{~mL})$ at $90{ }^{\circ} \mathrm{C}$ for $2 \mathrm{~h}$. The residue was partitioned between EtOAc and $\mathrm{H}_{2} \mathrm{O}$ to give the aglycone and sugar, respectively. The aqueous residue was concentrated to dryness under $\mathrm{N}_{2}$. The aqueous residue, D-glucose ( $2 \mathrm{mg}$ ), and D-xylose standard ( $2 \mathrm{mg}$ ) were separately dissolved in $0.5 \mathrm{~mL}$ anhydrous pyridine, and L-cysteine methyl ester hydrochloride $(2.0 \mathrm{mg})$ was then added. Each reaction mixture was heated at $60{ }^{\circ} \mathrm{C}$ for $1 \mathrm{~h}$, and then 2-methylphenyl isothiocyanate $(10 \mu \mathrm{L})$ was added to each reaction mixture and heated further for $1 \mathrm{~h}$. The reaction mixture $(0.5 \mathrm{~mL})$ was then analyzed by HPLC and detected at $250 \mathrm{~nm}$. Analytical HPLC was performed on a Welch Ultimate XB-C18 column $(4.6 \mathrm{~mm} \times 250 \mathrm{~mm}, 5$ microm $)$ at $35{ }^{\circ} \mathrm{C}$ with isocratic elution of $25 \% \mathrm{CH}_{3} \mathrm{CN}$ in $0.1 \% \mathrm{H}_{3} \mathrm{PO}_{4}$ for $40 \mathrm{~min}$ and subse- 
quent washing of the column with $90 \% \mathrm{CH}_{3} \mathrm{CN}$ at a flow rate $0.8 \mathrm{~mL} / \mathrm{min}$. Peaks at 16.54 and $19.64 \mathrm{~min}$ have coincided with derivatives of D-glucose and D-xylose [30].

\section{Supporting Information}

\section{Supporting Information File 1}

NMR, MS, UV, IR spectra and HPLC chromatogram of derivative 1.

[https://www.beilstein-journals.org/bjoc/content/ supplementary/1860-5397-18-23-S1.pdf]

\section{Acknowledgements}

We express our sincere thanks to Dr. Xiaonian Li and Jianchao Chen for their helpful assistance in NMR measurements.

\section{Funding}

This research was financially supported by the National Natural Science Foundation of China (Nos. 21977120 and 31770379), the Key Basic Research Program of the Science, Technology and Innovation Commission of Shenzhen Municipality (JCYJ20200109142215045), and the Hundred Talents Program of Sun Yat-sen University (No. 75110-18841218).

\section{ORCID ${ }^{\circledR}$ iDs}

Ying Guo - https://orcid.org/0000-0001-5129-0763

Yongbo Xue - https://orcid.org/0000-0001-9133-6439

\section{Preprint}

A non-peer-reviewed version of this article has been previously published as a preprint: https://doi.org/10.3762/bxiv.2021.87.v1

\section{References}

1. Lu, C.-L.; Zhu, L.; Piao, J.-H.; Jiang, J.-G. Pharm. Biol. (Abingdon, U. K.) 2012, 50, 225-231. doi:10.3109/13880209.2011.596207

2. Hua, P. Ann. Bot. (Oxford, U. K.) 2007, 99, 785. doi:10.1093/aob/mcm014

3. Li, Y.-M.; Zhu, L.; Jiang, J.-G.; Yang, L.; Wang, D.-Y. Curr. Pharm. Biotechnol. 2009, 10, 743-752. doi:10.2174/138920109789978748

4. Moshiashvili, G.; Tabatadze, N.; Mshvildadze, V. Fitoterapia 2020, 143, 104540. doi:10.1016/j.fitote.2020.104540

5. Venugopala, K. N.; Rashmi, V.; Odhav, B. BioMed Res. Int. 2013, 963248. doi:10.1155/2013/963248

6. Al-Warhi, T.; Sabt, A.; Elkaeed, E. B.; Eldehna, W. M. Bioorg. Chem. 2020, 103, 104163. doi:10.1016/j.bioorg.2020.104163

7. Su, X.; Wu, Y.; Wu, M.; Lu, J.; Jia, S.; He, X.; Liu, S.; Zhou, Y.; Xing, H.; Xue, Y. Molecules 2021, 26, 6955. doi:10.3390/molecules26226955
8. Jia, S.; Su, X.; Yan, W.; Wu, M.; Wu, Y.; Lu, J.; He, X.; Ding, X.; Xue, Y. Front. Chem. (Lausanne, Switz.) 2021, 9, 780304. doi:10.3389/fchem.2021.780304

9. Liang, S.; Shen, Y.-H.; Tian, J.-M.; Wu, Z.-J.; Jin, H.-Z.; Zhang, W.-D.; Yan, S.-K. Helv. Chim. Acta 2009, 92, 133-138. doi:10.1002/hlca.200800232

10. Liao, S.-G.; Zhang, B.-L.; Wu, Y.; Yue, J.-M. Helv. Chim. Acta 2005, 88, 2873-2878. doi:10.1002/hlca.200590230

11. Wang, Q.; Jiang, Y.; Luo, C.; Wang, R.; Liu, S.; Huang, X.; Shao, M. Bioorg. Med. Chem. Lett. 2018, 28, 626-629. doi:10.1016/.jbmcl.2018.01.036

12. Baba, K.; Taniguti, M.; Yoneda, Y.; Kozawa, M. Phytochemistry 1990, 29, 247-249. doi:10.1016/0031-9422(90)89043-9

13. Zhong, X.-N.; Otsuka, H.; Ide, T.; Hirata, E.; Takushi, A.; Takeda, Y. Phytochemistry 1997, 46, 943-946. doi:10.1016/s0031-9422(97)00366-x

14. Hara, H.; Ise, Y.; Morimoto, N.; Shimazawa, M.; Ichihashi, K.; Ohyama, M.; linuma, M. Biosci., Biotechnol., Biochem. 2008, 72, 335-345. doi:10.1271/bbb.70361

15. Machida, K.; Sakamoto, S.; Kikuchi, M. J. Nat. Med. 2009, 63, 227-231. doi:10.1007/s11418-009-0315-y

16. lizuka, M.; Warashina, T.; Noro, T. Chem. Pharm. Bull. 2001, 49 , 282-286. doi:10.1248/cpb.49.282

17. Salama, O.; Chaudhuri, R. K.; Sticher, O. Phytochemistry 1981, 20, 2603-2604. doi:10.1016/0031-9422(81)83110-x

18. Lee, D.-Y.; Song, M.-C.; Yoo, K.-H.; Bang, M.-H.; Chung, I.-S.; Kim, S.-H.; Kim, D.-K.; Kwon, B.-M.; Jeong, T.-S.; Park, M.-H.; Baek, N.-I. Arch. Pharmacal Res. 2007, 30, 402-407. doi:10.1007/bf02980211

19. Li, N.; Tan, N.; Zhou, J. Acta Bot. Yunnanica 2003, 25, 711-715.

20. Deyama, T.; Ikawa, T.; Nishibe, S. Chem. Pharm. Bull. 1985, 33 , 3651-3657. doi:10.1248/cpb.33.3651

21. Wang, C. Z.; Yu, D. Q. Phytochemistry 1998, 48, 711-717. doi:10.1016/s0031-9422(98)00019-3

22. Kaneko, T.; Ohtani, K.; Kasai, R.; Yamasaki, K.; Nguyen, M. D. Phytochemistry 1998, 47, 259-263. doi:10.1016/s0031-9422(97)00409-3

23. Çaliş, i.; Saracoğlu, i.; Başaran, A. A.; Sticher, O. Phytochemistry 1993, 32, 1621-1623. doi:10.1016/0031-9422(93)85194-v

24. Fukunaga, T.; Kajikawa, I.; Nishiya, K.; Takeya, K.; Itokawa, H. Chem. Pharm. Bull. 1989, 37, 1300-1303. doi:10.1248/cpb.37.1300

25. Lee, I.-S.; Kim, Y. S.; Jung, S.-H.; Yu, S. Y.; Kim, J.-H.; Sun, H.; Kim, J. S. Biosci., Biotechnol., Biochem. 2015, 79, 581-586. doi:10.1080/09168451.2014.991687

26. Dembitsky, V. M. Lipids 2005, 40, 869-900. doi:10.1007/s11745-005-1449-2

27. Al-Majedy, Y. K.; Kadhum, A. A. H.; Al-Amiery, A. A.; Mohamad, A. B. Syst. Rev. Pharm. 2017, 8, 62-70. doi:10.5530/srp.2017.1.11

28. Wu, Y.; Xie, S.-s.; Hu, Z.-x.; Wu, Z.-d.; Guo, Y.; Zhang, J.-w.; Wang, J.-p.; Xue, Y.-b.; Zhang, Y.-h. Chin. Herb. Med. 2017, 9 , 193-196. doi:10.1016/s1674-6384(17)60095-9

29. Zhang, N.; Shi, Z.; Guo, Y.; Xie, S.; Qiao, Y.; Li, X.-N.; Xue, Y.; Luo, Z.; Zhu, H.; Chen, C.; Hu, L.; Zhang, Y. Org. Chem. Front. 2019, 6, 1491-1502. doi:10.1039/c9qo00245f

30. Tanaka, T.; Nakashima, T.; Ueda, T.; Tomii, K.; Kouno, I. Chem. Pharm. Bull. 2007, 55, 899-901. doi:10.1248/cpb.55.899 


\section{License and Terms}

This is an open access article licensed under the terms of the Beilstein-Institut Open Access License Agreement (https://www.beilstein-journals.org/bjoc/terms), which is identical to the Creative Commons Attribution 4.0 International License

(https://creativecommons.org/licenses/by/4.0). The reuse of material under this license requires that the author(s), source and license are credited. Third-party material in this article could be subject to other licenses (typically indicated in the credit line), and in this case, users are required to obtain permission from the license holder to reuse the material.

The definitive version of this article is the electronic one which can be found at:

https://doi.org/10.3762/bjoc. 18.23 